Jpn. J. Oral Biol., $27:$ 132-139, 1985.

\title{
マウス有郭乳頭味蕾のセロトニンの免疫組織化学
}

\author{
内田隆 \\ 山梨医科大学解剖学教室 (主任 : 小林 繁教授)
}

〔受付 : 昭和59年 9 月 20 日〕

\section{Serotonin-like immunoreactivity in the taste bud of the mouse circumvallate papilla}

\author{
Takashi Uchida \\ Department of Anatomy, Yamanashi Medical School \\ Tamaho, Yamanashi 409-38 \\ (Chief: Prof. Shigeru Kobayashi) \\ [Accepted for publication September 20, 1984]
}

Key words : taste bud / serotonin-like immunoreactivity/immunocytochemistry / protein A-colloidal gold method

\begin{abstract}
Serotonin-like immunoreactivity in the circumvallate taste buds of untreated and serotoninor 5-hydroxytryptophan (5-HTP, a precursor of serotonin)-treated mice were investigated by a modified PAP method with light microscopy and protein A-colloidal gold method with electron microscopy. As a control, supraependymal nerve plexus was immunostained by the same method.

In both untreated and serotonin-treated mice, no specific immunostaining was seen in the taste bud, whereas supraependymal nerve plexuses of the lateral and third ventricles contained nerve fibers showing a distinct serotonin-like immunoreactivity. After intraperitoneal injection of 5-HTP, some taste bud cells showed serotonin-like immunoreactivity. Under electron microscopy, colloidal gold particles representing serotonin-like immunoreactivity were seen in the cytoplasm, nucleus and dense-cored vesicles in the type III cell. Positive immunoreaction of the taste bud and supraependymal nerve plexus disappeared by preincubation of the anti-serotonin serum with serotonin-creatinine sulfate. Immunostaining was not affected by preincubation of the antiserum with 5-HTP.

Functional significance of 5-HTP uptake and serotonin synthesis in the type III cell was discussed with particular refernce to taste sensation.
\end{abstract}

\section{緒言 \\ マウス有郭乳頭味蕾には，モノアミンの前駆} 物質である5-ハイドロキシトリプトファン（5HTP) や L-DOPA を取り込む能力を持つ細胞が 存在することが, 螢光組織化学によって示されて いる ${ }^{1-3)}$ 。Takeda らは無処置マウスと 5-HTPを 投与したマウスの味蕾の微細構造を比較し, 味蕾 を構成する細胞のうち，III型細胞が 5-HTP を取 り込み，七ロトニンに転換して大型芯あり小胞と 小型のシナプス小胞に貯蔵すると予想した ${ }^{2,3)}$ 。そ 山梨県中巨摩郡玉穂村下河東 1110 (广 409-38)
して電顕オートラジオグラフにより 5 -HTP が III 型細胞に取り込まれることを証明したが，芯あり 小胞とシナプス小胞に ${ }^{3} \mathrm{H}-5-\mathrm{HTP}$ 由来の銀粒子を 認めることはできなかったと報告しており ${ }^{41}$ ，芯 あり小胞やシナプス小胞がセロトニンを含むかど うかは明らかにされていない。また螢光組織化学 では，モノアミンの他にその前駆物質である5HTP や L-DOPA もホルムアルデヒドと縮合し て螢光性の物質を作る。そしてモノアミン由来の 螢光とモノアミン前駆物質由来の螢光を区別する ことはきわめて困難である ${ }^{5)}$ 。従って III型細胞に 取り込まれた 5-HTP がセロトニンに転換されて 
いるか否かも推測の域を出ない。

Steinbusch らによって開発されたセロトニンの 免疫組織化学は螢光組織化学やオートラジオグラ フに比へ，感度，特異性とも優れており ${ }^{61}$ ，電顕観 察も可能である。本研究はセロトニンの免疫組織 化学を用いて，マウス有郭乳頭味蕾のセロトニン の局在を光顕および電䫓レベルで明らかにするこ とを目的とする。

\section{材料および方法}

\section{1. 実験材料}

体重30 40g の雄の $\mathrm{dd}$ 系マウスの有郭乳頭 を使用し，対照として第 3 脳室と側脳室壁に分布 するセロトニンニューロンを用いた。これは多く の動物で脳室壁に豊富なセロトニンニューロンが 分布していることが明らかにされており?，中枢 神経内における位置の同定も容易なためである。

動物は 3 群に分け，第 1 群は無処置のままと し，第 2 群は固定 1 時間から 1 時間30分前にセ口 トニンクレアチニン硫酸 (Merk, 60〜100mg/kg) を腹腔内投与し，第 3 群には同様にして 5-HTP （半井化学， $60 \sim 100 \mathrm{mg} / \mathrm{kg}$ ）を投与した。

\section{2. 抗血清}

抗セロトニン血清は，セロトニンクレアチニン 硫酸をウシ血清アルブミン（BSA）とホルムアル デヒドで結合させたものを免疫抗原とし，ウサギ を感作して得られたものを使用した。この抗セ口 トニン血清の詳細についてはすでに 発表されてい $ろ^{8)}$ 。

\section{3. 光顕免疫組織化学}

ヘパリン投与 $(1,000 \mathrm{IU} / \mathrm{kg})$ した動物をペント バルビタールナトリウム麻酔下 $(50 \mathrm{mg} / \mathrm{kg})$ で開 胸し, 左心室から水冷した $4 \%$ パラホルムアルデ ヒドー $0.2 \%$ ピクリン酸一 $0.067 \mathrm{M}$ 燐酸緩衝液, $\mathrm{pH} 7.2$ で灌流固定した。舌と大脳を取り出し, 厚 さ3 $\mathrm{mm}$ 以下のスライスとして同固定液にさらに $4{ }^{\circ} \mathrm{C}, 12 \sim 24$ 時間浸漬後, 厚さ $15 \sim 20 \mu \mathrm{m}$ の凍結 切片を作製し, 免疫組織化学の材料とした。

内因性ペルオキシダーゼ活性と 赤血球のカタラ 一ゼ様活性を阻止するためには，切片を $\mathrm{PBS}$ (燐 酸緩衝生理食塩水; $0.01 \mathrm{M}, \mathrm{pH} 7.2, \mathrm{NaCl} 8 \mathrm{~g} / l$ ) 中で $65^{\circ} \mathrm{C}, 30$ 分間加熱し, 次で $3 \%$ 過酸化水素
を含むPBS で室温10分間処理した。

免疫染色は浮遊切片法による PAP 法9'で行な い，抗セロトニン血清は 16,000 倍に希釈して $4{ }^{\circ} \mathrm{C} ， 18 \sim 24$ 時間作用させた。二次血清や PAP 複合体の希釈倍率, 時間については Takeuchi ら の方法" ${ }^{9}$ に従った。

\section{4. 電顕免疫組織化学}

光顕用と同様にして動物は $4 \%$ パラホルムアル デヒドー $0.2 \%$ ピクリン酸— $0.4 \%$ グルタールアル デヒドー0.067M 燐酸緩衝液, $\mathrm{pH} 7.2$ で灌流固定 した。有郭乳頭と第 3 脳室後下壁部を取り出し, 細切して上記の固定液から グルタールアルデヒド を除いた液でさらに $4{ }^{\circ} \mathrm{C} ， 12 \sim 24$ 時間固定した。 固定後の 試料は低温下でグリコールメタクリレー ト（メタクリル酸ハイドロキシェチル， GMA）に

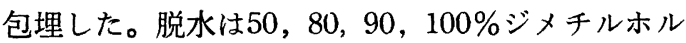

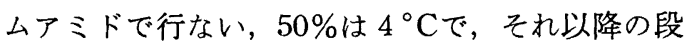
階は $-20^{\circ} \mathrm{C}$ で各々 30 分つ゚つかけた。その後試料 は GMA 混合液に移し， $-20^{\circ} \mathrm{C}$ で 24 時間浸透さ せた後にゼラチンカプセルに包埋した。重合は一 $20^{\circ} \mathrm{C}$ で 24時間紫外線照射して行なった。GMA 混合液は Leduc と Bernhard の処法 ${ }^{10}$ を改変した もので， GMA70ml，メタクリル酸-n-ブチル25 $\mathrm{m} l$, ジメタクリル酸エチレングリコール $5 \mathrm{~m} l$ に, 触媒としてベンゾインメチルエーテル $0.5 \mathrm{~g}$ を加 えたものである。

超薄切片はプロテイン A ・金コロイド法 ${ }^{11,12)}$ 免疫染色した。抗セロトニン血清は 2,000 倍から 4,000倍に希䣋し， $4{ }^{\circ} \mathrm{C}$ で12〜18時間または室温 で $3 \sim 4$ 時間反応させた。プロテイン $\mathrm{A} ・$ 金コロ イド複合体は, Slot と Geuze の方法 ${ }^{12}$ に従って塩 化金酸をアスコルビン酸ナトリウムで還元して作 った金粒子をプロテインA（Pharmacia Fine Chem., Uppsala, Sweden) と結合させ,さらにグリ セリン濃度句配で金粒子の直径が $6 \sim 8 \mathrm{~nm}$ のも のを分離して使用した。

\section{5. 免疫組織化学の特異性の検定}

免疫組織化学の特異性を調べるため, 抗セロト ニン血清のかわりにPBS または希釈した正常ウ サギ血清を用いて免疫染色を行なった。

吸収試験としては，希釈した抗セロトニン血清 にセロトニンクレアチニン硫酸と BSA をホルム 
アルデヒドで結合させたもの（免疫抗原と同じ方 法で作製したもの，100 $\mathrm{g} / \mathrm{m} l) ， \mathrm{BSA}(1 \mathrm{mg} / \mathrm{m} l)$, セロトニンクレアチニン硫酸 $(0.1 \sim 20 \mathrm{mM}) ， 5$ HTP (0.1 20mM) および 5-ハイドロキシイ ンドール-3-酢酸（半井化学, $0.1 \sim 20 \mathrm{mM}$ ) を加 え, $4{ }^{\circ} \mathrm{C}$, 暗所で 1 晚反応させたものを一次血清 のかわりに使用して免疫染色を行なった。

\section{結果}

\section{1. 光顕免疫組織化学}

無処置およびセロトニンを投与したマウスで は，味蕾内にセロトニン様免疫活性を示す細胞は 全く認められなかった。しかし粘膜固有層の肥満 細胞と対照として用いた脳室壁のセロトニンニュ 一ロンは明瞭なセロトニン様免疫活性を示した。

セロトニンの前駆物質である 5-HTP を投与 すると, 一部の味蕾細胞がセロトニン様免疫活性 を示した。この細胞は基底膜から味孔部まで達す る長紡鍾形で, 厚さ約 $15 \mu \mathrm{m}$ の切片では 1 つの味 蕾内に $2 \sim 8$ ケ存在した。核を含む細胞体から味
孔部と基底膜一向う突起は細く，分枝は認められ なかった。免疫活性の強さは細胞ごとに種々であ ったが，一つの細胞内では細胞質はほぼ均一な強 さで染色され，核も細胞質よりやや弱い免疫活性 を示した（Fig. 1)。

\section{2. 電顕免疫組織化学}

無処置およびセロトニンを投与したマウスの味 蕾内には，七ロトニン様免疫活性の局在を示す金 粒子の集積は全く認められなかった。マウス有郭 乳頭味蕾を構成している細胞は，I 型，II型， III 型の 3 型に分類されている ${ }^{13)}$ 。 III型細胞は神経終 末とシナプスを形成していることと, 直径約 $80 \mathrm{~nm}$ の芯あり小胞を含むことで同定されたが，シナプ ス小胞は識別困難で，芯あり小胞に免疫活性は全 く認められなかった。対照として用いた脳室壁に はセロトニン様免疫活性を示す神経線維が認めら れた。免疫活性の局在を示す金粒子は主として直 径 80 100nm の芯あり小胞に集積していたが, 細胞質中にも小数ながら 金粒子が認められた。

5-HTP 投与群では 味蕾内の III型細胞が セロ

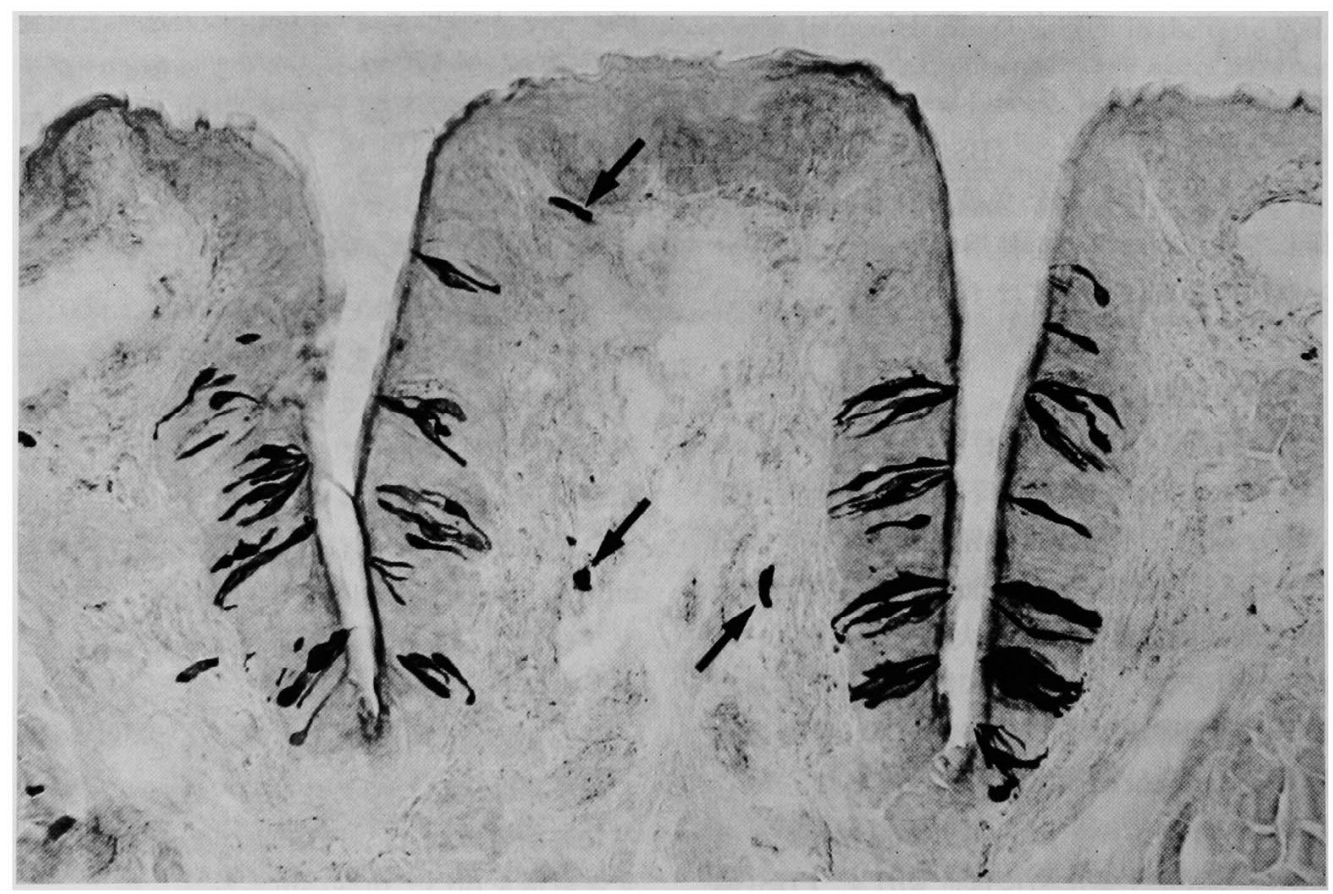

Fig. 1 A light micrograph of a circumvallate papilla from a 5-HTP-treated mouse. A number of serotonin-like immunoreactivity containing cells are seen in the taste buds. Mast cells (arrows) in lamina propria also show serotonin-like immunoreactivity. $\times 360$ 


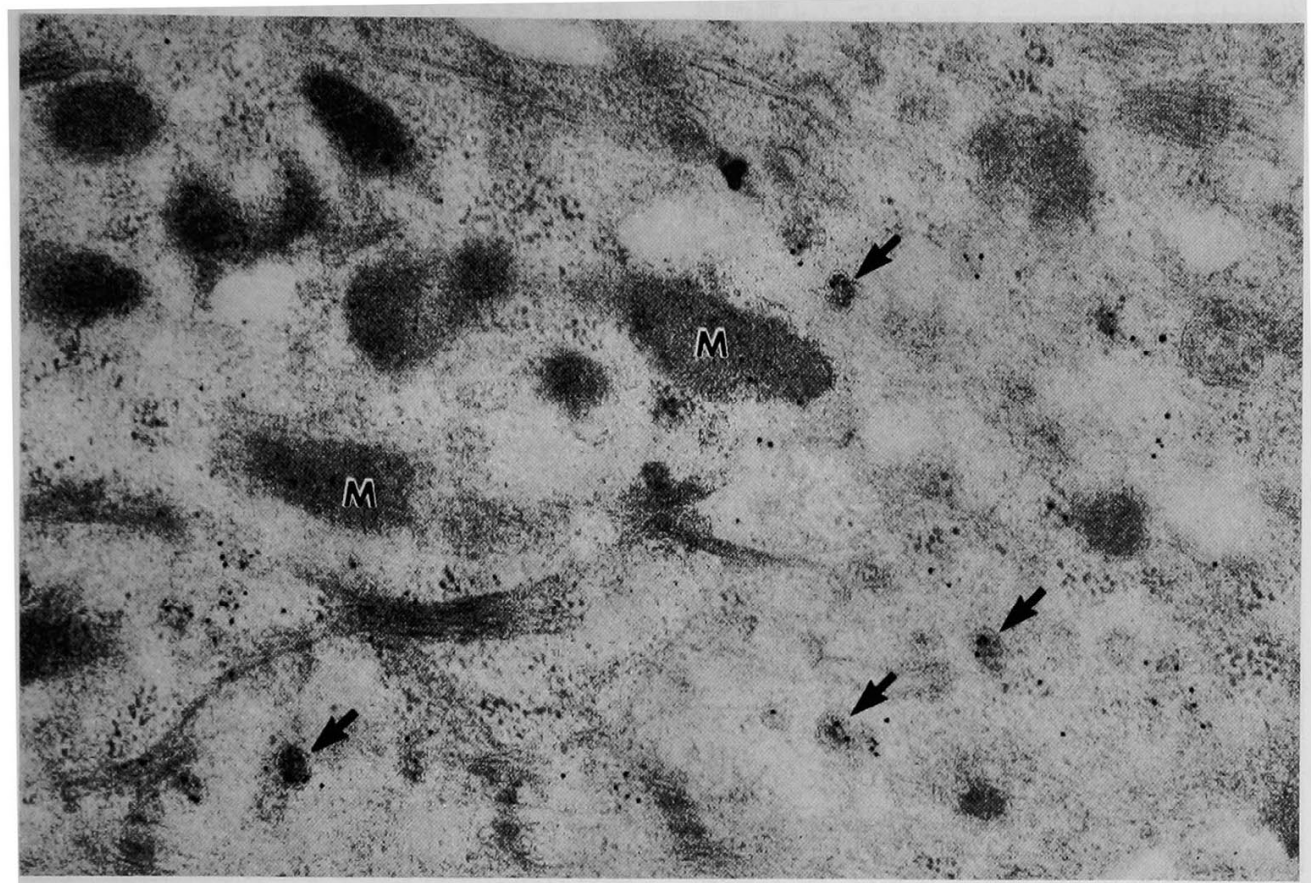

Fig. 2 Ultrastructural localization of serotonin-like immunoreactivity in altype $\mathbf{I I I}$ cell from a 5HTP-treated mouse taste bud. Colloidal gold particles are seen in the dense-cored vesicles (arrows), mitochondria (M) and cytoplasm. $\times 46,000$

トニン様免疫活性を示した。免疫活性の強さ（金 粒子の分布密度）は細胞ごとに異なっていたが, 細胞質全体に免疫活性が認められた。核とミトコ ンドリアにも 細胞質と同程度あるいはやや弱い免 疫活性が認められたが，粗面小胞体とゴルジ層板 内腔はほとんど免疫活性を示さなかった。芯あり 小胞も免疫活性を示したが，免疫活性を示さない ものも認められた (Fig. 2)。前シナプス部に集積 していると考えられるシナプス小胞の識別は 困難 で，芯を持つかどうかも不明であった。また免疫 活性は前シナプス部に強いとはいえなかった (Fig. 3)。

I 型と II 型の味蕾細胞, 味蕾内の神経終末，味 蕾周囲の重層扁平上皮と結合組織には全く免疫活 性は認められなかった（Figs. 2，3）。

3. 免疫組織化学の特異性の検定

抗セロトニン血清の代わりに PBS または希釈 した正常ウサギ血清を用いた場合には，反応は全 く認められなかった。

抗セロトニン血清にセロトニンクレアチニン硫
酸と BSA をホルムアルデヒドで結合させたもの を加えた場合, 免疫活性は完全に消失した。セ口 トニンクレアチニン硫酸を加えた場合, 光顕では $0.5 \mathrm{mM}$ で味蕾内とセロトニンニューロンの反応 は著しく減弱し， $2 \mathrm{mM}$ で完全に消失した。電顕 では $5 \mathrm{mM}$ のセロトニンクレアチニン硫酸を加え ることによって免疫活性は消失した。

抗セロトニン血清に 5-HTP または 5-ハイド ロキシインドールー3-酢酸を $0.1 \sim 20 \mathrm{mM}$ 加えた 場合および BSA を $1 \mathrm{mg} / \mathrm{ml}$ 加えた場合には, 免疫活性に全く変化は認められなかった。

\section{考察}

本研究は マウス有郭乳頭味蕾のセロトニン様免 疫活性の局在を明らかにした。すなわち無処置お よびセロトニンを投与したマウスの味蕾には全く 免疫活性を認めなかったが，5-HTP 投与後のマ ウスでは味蕾内にセロトニン様免疫活性を示す細 胞が出現し, 電顕免疫組織化学ではIII型細胞に免 疫活性が認められた。本研究で用いた抗セロトニ 


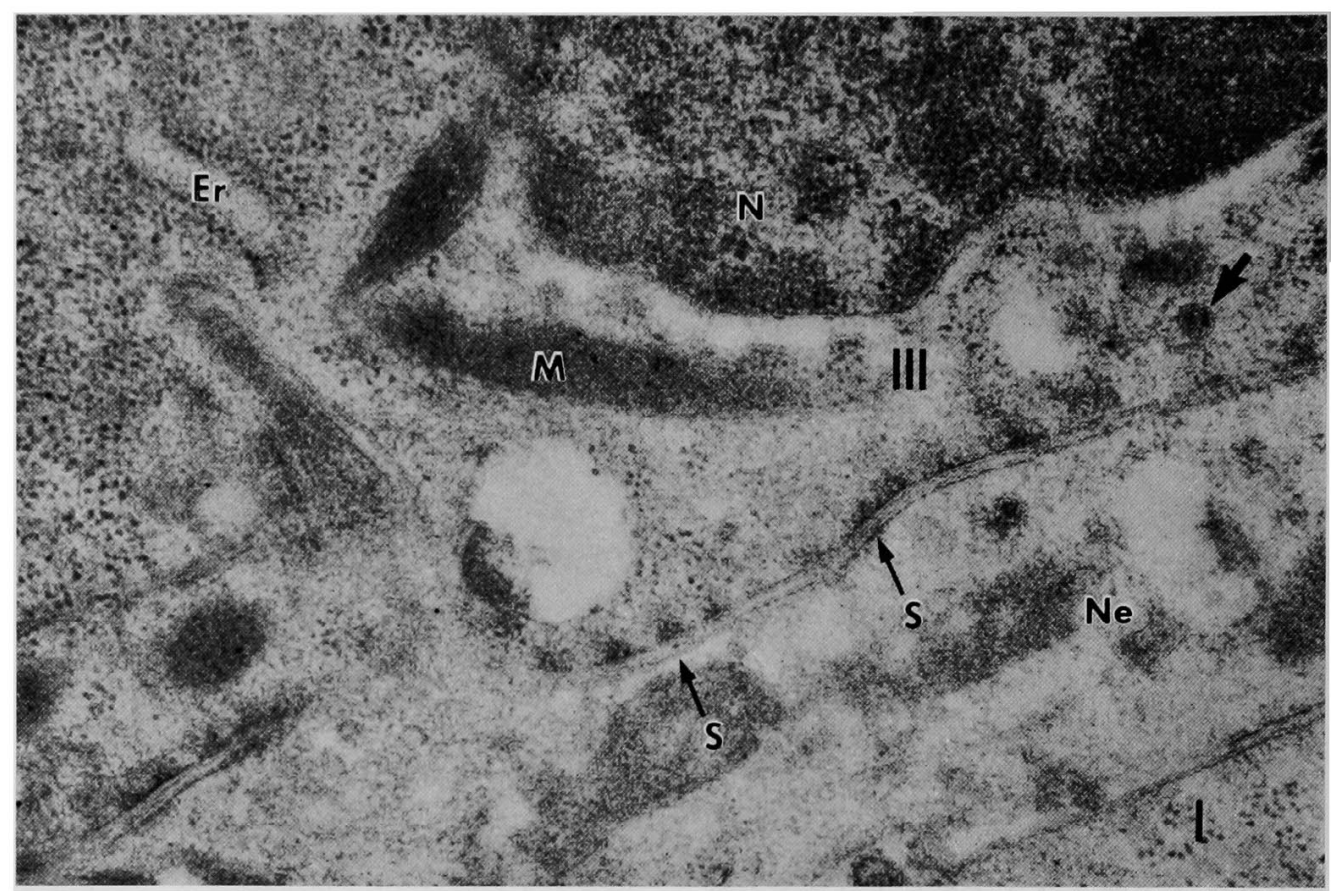

Fig. 3 A synaptic contact (s) between a type III cell (III) and a nerve ending ( $\mathrm{Ne}$ ) from a 5 . HTP-treated mouse taste bud. Serotonin-like immunoreactivity is seen in the dense-coerd vesicle (arrow), nucleus (N), mitochondria (M) and cytoplasm of the type III cell. Endoplasmic reticulum $(\mathrm{Er})$ is devoid of serotonin-like immunoreactivity. Synaptic type vesicles are not distinguishable in the presynaptic region. Nerve ending and type I cell (I) show no serotonin-like immunoreactivity. $\times 42,000$

ン血清の特異性については,すでに NishiitsutsujiUwo らによって報告されており，免疫組織化学 に使用した場合は組織内のセロトニンと特異的に 反応することが明らかにされている8 。吸収試験 の結果は本研究で用いた免疫組織化学系がセロト ニンに特異的であり，投与した 5-HTP やセロト ニンの 主要代謝産物である5-ハイドロキシイン ドールー3-酢酸とほとんど交叉反応をおこさない ことを示している。以上の結果からマウス有郭乳 頭味蕾の III型細胞が 5-HTP を取り込み，脱炭酸 してセロトニンに転換し，これを細胞内に貯蔵し ていることが明らかとなった。III型細胞がアミン 前駆体を取り込む能力を持つことはすでにオート ラジオグラフによって明らかにされていた ${ }^{4)}$ 。取 り込まれたアミン前駆体はモノアミンに転換さ れて細胞内に貯蔵されていると予想されていた が2-4)，本研究は免疫組織化学の 持つ鋭い特異性 を利用し，詳細な吸収試験を行なうことによって
これを証明したといえる。

マウス味蕾の III型細胞は芯あり小胞とシナプス

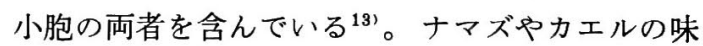
覚器には生理的状態でセロトニンを含有している 細胞が存在し ${ }^{14,15)}, こ の$ 細胞は多数の芯あり小胞 を含むため ${ }^{14,16)}$ ，七ロトニンは芯あり小胞中に貯 蔵されていると考えられている14,17)。マウス味蕾 においては nialamide の前処置後, 5-HTP を投与 することにより， III型細胞の芯あり小胞の数が増 加し, 芯の電子密度が高くなり，またシナプス小 胞に芯を持っものが出現するという ${ }^{2,3)}$ 。このこと から芯あり小胞とシナプス小胞の両者に七ロトニ ンが含まれていると考えられていた ${ }^{3}$ 。しかし電 顕オートラジオグラフでは，投与した ${ }^{3} \mathrm{H}-5-\mathrm{HTP}$ 由来の銀粒子はIII型細胞の核と細胞質に認めら れ，芯あり小胞とシナプス小胞には認められなか ったと報告されている4 。本研究の電顕免疫組織 化学では芯あり小胞にセロトニン様免疫活性を検 
出することができた。しかし大部分の金粒子は核 と細胞質全域に出現し, 免疫活性を示さない芯あ り小胞も認められた。またシナプス小胞には明瞭 な免疫活性を認めることはできなかった。

水溶性のセロトニンがどのようにして組織中に 固定され，不溶化されるかはよくわかっていな い。しかし，固定液中のホルムアルデヒドによ り, Mannich 反応と類似の反応によって組織中 の蛋白質とセロトニンが結合し，不溶性になると 考えられている(18)。この場合固定中にセロトニン が拡散によって移動し，本来の局在部位とは異な る場所で不溶化される可能性もある。しかしIII型 細胞と接する他の味蕾細胞や神経終末, 結合組織 には全く免疫活性は認められず， III型細胞内でも ゴルジ層板や粗面小胞体内腔には免疫活性はほと んど検出されなかった。この結果は固定中にセ口 トニンが移動して他の場所で不溶化された可能性 がほとんどないことを示していると考えられ，電 顕レベルで検出された セロトニン様免疫活性の局 在は本来のセロトニンの局在を 正しく反映してい る可能性が強い。すなわち III型細胞内で合成され たセロトニンの一部は芯あり小胞に取り込まれる が，大部分は細胞質中と核内に存在していると考 えられる。

今回の研究では シナプス小胞に明瞭なセロトニ ン様免疫活性を検出することはできなかった。

Schipper と Tilder によるゼラチンモデルの実験 では， $4 \%$ \%゚ラホルムアルデヒド固定と洗浄の間 に約 $50 \%$ のセロトニンが流失すると報告されてい る ${ }^{19)}$ 。組織中でも同様なことが起こると考えら れ，シナプス小胞中にセロトニンが含まれている か否かを確認するためには, 組織中の物質の流失 がより少ない方法, 例えば凍結乾燥法によって調 べることが必要と思われる。

哺乳動物の味蕾では III型細胞のみが神経終末と 求心性シナプスを形成している ${ }^{13,20-22) 。 乙 れ ゆ え ~}$ 味蕾が味覚の受容・伝達と関係しているとすれ ば， III型細胞が受容細胞であると予想されてい $3^{13,20-22)}$ 。ウサギ味蕾のIII型細胞は生理的状態で

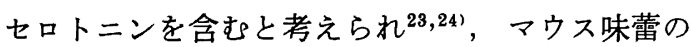
III 型細胞もアミン前駆体を取り込む能力を持 $つ^{2-4)}$ 。それゆえ III型細胞から神経終末への化学伝
達物質としてはセロトニン，ノルアドレナリン等 のモノアミンが候補としてあげられている。しか しマウスでは生理的状態でモノアミンの存在を味 蕾内に証明した報告はなく，アミン前駆体を投与 した場合にのみモノアミンの螢光が 観察されてい る $^{1-4)}$ 。本研究では螢光組織化学より高感度である と考えられる免疫組織化学を用いて 検索したが, 生理的状態では味蕾内にセロトニン様免疫活性を 検出できなかった。しかし対照として用いたセロ トニンニューロンには明瞭な免疫活性が認められ た。この結果は生理的状態ではマウス有郭乳頭味 蕾の III型細胞のセロトニン含有量は, セロトニン ニューロンのセロトニン含有量よりも著しく少な く，あるいはほとんどないことを示しており，七 ロトニンが III型細胞から神経終末への化学伝達物 質である可能性は低いと考えられる。

Larsson ${ }^{25}$, Probert ら ${ }^{26)}$ は結腸の Auerbach 神 経叢内の神経細胞や神経終末に含まれる芯あり小 胞のうち, あるものはVIP を含み, あるものは $\mathrm{P}$ 物質を含むことを, 電顕免疫組織化学により示 した。味蕾内の細胞にペプチドを見出した報告は ないが， III型細胞の芯あり小胞にペプチドが含ま れ，これが神経伝達物質として作用している可能 性は十分考えられる。

\section{結 論}

マウス有郭乳頭味蕾におけるセロトニンの局在 を光顕および電顕免疫組織化学で調べた。その結 果, 味蕾の III型細胞が 5-HTP を取り込み, セ口 トニンに転換していることが明らかになり，七ロ トニンの一部は芯あり小胞に貯蔵されるが，大部 分は細胞質中に存在すると考えられた。また生理 的状態でIII型細胞にセロトニン様免疫活性は認め られず， III型細胞から神経終末への化学伝達物質 としてセロトニン以外の物質が関係していると考 えられた。

謝辞: 本研究ではシオノギ研究所宇尾淳子博士が作製 された抗セロトニン血清を使用させていただきました。 ここに深謝します。 
抄録：無処置およびセロトニンまたはセロトニンの前駆物質である 5 -八イドロキシトリプトファン（5HTP）を投与したマウスの有郭乳頭味蕾について, 光顕では浮遊切片法を用いた PAP 法で, 電顕ではプロ ティン A・金コロイド法でセロトニン様免疫活性の局在を調べた。また対照として側脳室壁と第 3 脳室壁に 分布する supraependymal nerve plexus を同一の方法で免疫染色した。

無処置およびセロトニンを投与したマウスでは，味蕾内にセロトニン様免疫活性 は全く認められなかった が, supraedymal nerve plexus 内には明膫なセロトニン様免疫活性を示す神経線維が喼められた。5-HTP 投 与後のマウスでは, 味蕾内の一部の細胞が セロトニン様免疫活性を示し, 電顕免疫組織化学では而型細胞の 細胞質, 核, 芯あり小胞に免疫活性が認められた。これらの免疫活性は抗セロトニン血清をセロトニンクレ アチニン硫酸で吸収させることにより完全に消失したが，5-HTP によって免疫活性は影響されなかった。

マウス有郭乳頭味蕾の而型細胞は, 5-HTP を取り込みこれをセロトニンに転換する能力を持っているが, 生理的状態ではほとんどセロトニンを含まず，七ロトニン以外の化学伝達物質が血型細胞から 神経終末への 味覚伝達に関係している可能性が考えられた。

\section{文献}

1) Geerdink, H. G. and Drukker, J.: Uptake of L-Dopa by cells in the taste buds of the vallate papilla of the mouse. Histochemie $36: 219-223,1973$.

2) Takeda, M.: Uptake of 5-hydroxytryptophan by gustatory cells in the mouse taste bud. Arch. Histol. Jpn. 40 : 243-250, 1977.

3) Takeda, M. and Kitao, K.: Effect of monoamines on the taste buds in the mouse. Cell Tiss. Res. 210 : 71-78, 1980.

4) Takeda, M. and Suzuki, Y.: An autoradiographic study of the taste bud following injections of labeled biogenic amine precursors. J. Electron Microsc. 32 : 357-360, 1983.

5) Ritzén, M. : Quantitative fluorescence microspectrophotometry of 5-hydroxytryptamineformaldehyde products in models and in mast cells. Exp. Cell Res. 45 : 178-194, 1966.

6) Steinbusch, H. W. M., Verhofstad, A. A. J. and Joosten, H. W. J. : Localization of serotonin in the central nervous system by immunohistochemistry : description of a specific and sensitive technique and some applications. Neuroscience 3:811-819, 1978.

7) Sano, Y., Takeuchi, Y., Kimura, H., Goto, M., Kawata, M., Kojima, M., Matsuura, T., Ueda, S. and Yamada, H. : Immunohistochemical studies on the processes of serotonin neurons and their ramification in the central nervous system-with regard to the possibility of the existence of Golgi's rete nervosa diffusa. Arch. Histol. Jpn. 45 : 305-316, 1982.

8) Nishiitsutsuji-Uwo, J., Takeda, M. and Saito, H.: The production of an antiserum to serotonin and serotonin-like immunoreactivity in the cockroach brain-midgut system. Biomed. Res. 5 : 211-224, 1984.
9) Takeuchi, Y., Kimura, H. and Sano, Y.: Immunohistochemical demonstration of the distribution of serotonin neurons in the brain. stem of the rat and cat. Cell Tiss. Res. 224 : 247-267, 1982.

10) Leduc, E. H. and Bernhard, W.: Recent modifications of the glycol methacrylate embedding procedure. J. Ultrastr. Res. 19 : 196-199, 1967.

11) Roth, J., Bendayan, M. and Orci, L.: Ultrastructural localization of intracellular antigens by the use of protein A-gold complex. J. Histochem. Cytochem. 26 : 1074-1081, 1978.

12) Slot, J. W. and Geuze, H. J.: Sizing of protein A-colloidal gold probes for immunoelectron microscopy. J. Cell Biol. 90 : 533536, 1981.

13) Takeda, M.: An electron microscopic study on the innervation in the taste buds of the mouse circum vallate papillae. Arch. Histol. Jpn. 39 : 257-269, 1976.

14) Reutter, K.: Die Geschmacksknospen des Zwergwelses Amiurus nebulosus (Lesueur). Morphologische und histochemische Untersuchungen. Z. Zellforsch. $120:$ 280-308, 1971.

15) Goossens, N. and Vandenberghe, M.-P. : The basal cells in the papillae fungiformes of the tongue of the common frog, Rana temporaria L. Arch. Histol. Jpn. 36 : 173179, 1974.

16) Düring, M. v. and Andres, K. H. : The ultrastructure of taste and touch receptors of the frog's taste organ. Cell Tiss. Res. 165 : 185-198, 1976.

17) Hirata, K. and Nada, O.: A monoamine in the gustatory cell of the frog's taste organ. A fluorescence histochemical and electron microscopic study. Cell Tiss. Res. 159 : 101- 
108, 1975.

18) Brusco, A., Peressini, S. and Saavedra, J. P.: Serotonin-like immunoreactivity and anti-5-hydroxytryptamine (5-HT) antibodies : Ultrastructural application in the central nervous system. J. Histochem. Cytochem. 31 : 524-530, 1983.

19) Schipper, J. and Tilders, F. J. H. : A new technique for studying specificity of immunocytochemical procedures: Specificity of serotonin immunostaining. J. Histochem. Cytochem. 31 : 12-18, 1983.

20) Murray, R. G., Murray, A. and Fujimoto, S.: Fine structure of gustatory cells in rabbit taste buds. J. Ultrastr. Res. 27 : 444461, 1969.

21) Takeda, M. and Hoshino, T. : Fine structure of taste buds in the rat. Arch. Histol. Jpn. 37 : 395-413, 1975.

22) Paran, N., Mattern, C. F. T. and Henkin,
R. I. : Ultarstructure of the taste bud of the human fungiform papilla. Cell Tiss. Res. 161 : $1-10,1975$.

23) Nada, O and Hirata, K.: The occurrence of the cell type containing a specific monoamine in the taste bud of the rabbit's foliate papilla. Histochemistry $43: 237-240,1975$.

24) Nada, O and Hirata, K. : The monoaminecontaining cell in the gustatory epitherium of some vertebrates. Arch. Histol. Jpn. 40 (Suppl.): 197-206, 1977.

25) Larsson, L. -I. : Ultrastructural localization of a new neuronal peptide (VIP). Hitochemistry 54 : 173-176, 1977.

26) Probert, L., De May, J. and Polak, J. M. : Distinct subpopulations of enteric p-type neurones contain substance $\mathrm{P}$ and vasoactive intestinal polypeptide. Nature 294 : 470-471, 1981. 